\title{
Opportunities and challenges for the implementation of REDD+ activities in India
}

\author{
R. S. Rawat*, Gurveen Arora, Shilpa Gautam and Trishla Shaktan
}

$R E D D+$ is one of the climate change mitigation options in the forestry sector in developing countries, which is under different phases of implementation. India is under the readiness phase of REDD+ implementation, and has developed National REDD+ Strategy and Forest Reference Level. Relevant policies, laws and regulations related to forest resources support the implementation of REDD+ activities. Lack of capacity of the stakeholders on REDD+ related issue, as well as lack of availability of adequate quality planting stocks, and readily available international and national finance are identified as the challenges for implementation of REDD+ activities in India.

Keywords: Climate change, greenhouse gas emissions, forest sector mitigation options, REDD+ activities.

GLOBALLY, agriculture, forestry and other land-use (AFOLU) activities account for about 23\% (52 $\mathrm{GtCO}_{2}$ year $^{-1}$ ) of total net anthropogenic emissions of greenhouse gases (GHGs). The GHG emission from deforestation and forest degradation have been reported to be $5.8 \mathrm{GtCO}_{2}$ year ${ }^{-1}$, which is $11 \%$ of total emission from AFOLU activities ${ }^{1}$. Policy approaches aiming towards reduction in deforestation and forest degradation can reduce emissions from forests, and sustainable management has enormous potential to enhance carbon capture and storage by the forests.

The Conference of Parties (COP) of the United Nations Framework Convention on Climate Change (UNFCCC) agreed that the Parties should collectively aim to slow, halt and reverse forest cover and carbon loss. Accordingly, the concept of reducing emissions from deforestation and forest degradation in developing countries (REDD) was introduced under UNFCCC in 2005. India proposed a policy approach regarding compensated conservation, to compensate countries for conservation and enhancement of their forest cover. India's concern was recognized in COP 13 of UNFCCC and incorporated in the Bali Action Plan (Decision 1/CP.13) as 'Policy approaches and positive incentives on issues relating to reducing emissions from deforestation and forest degradation in developing countries; and the role of conservation, sustainable management of forests and enhancement of forest carbon stocks in developing countries'. After inclusion of the role of conservation, sustainable management of forests and enhancement of forest carbon stocks, the concept of REDD became REDD+, one of the climate change mitigation options in the forest sector in developing countries ${ }^{2}$.

R. S. Rawat, Gurveen Arora and Shilpa Gautam are in the Indian Council of Forestry Research and Education, Dehradun, 248 006, India and Trishla Shaktan is in the Forest Research Institute, Dehradun 248 006, India.*For correspondence. (e-mail: rsbrawat@gmail.com)
The Cancun Agreements (Decision 1/CP.16) on REDD+ 'encourage developing country Parties to contribute to mitigation actions in the forest sector by undertaking the activities (reducing emissions from deforestation, reducing emissions from forest degradation, conservation of forest carbon stocks, sustainable management of forest and enhancement of forest carbon stocks) as deemed appropriate by each country Party and in accordance with their respective capabilities and national circumstances'. The Cancun Agreements further encourages developing country Parties to take up REDD+ activities in order to develop a national strategy or action plan, national forest reference emission level and/or forest reference level, national forest monitoring system and safeguards information system ${ }^{3}$. According to the Cancun Agreements, a set of seven safeguards (actions that complement or are consistent with the objectives of national forest programmes and appropriate international conventions and hence agreements; transparent and effective national forest governance structures, taking into account national legislation and sovereignty; respect for knowledge and rights of indigenous people and members of local communities; full and effective participation of relevant stakeholders; actions consistent with the conservation of natural forests and biological diversity; actions to address the risks of reversals and actions to reduce displacement of emissions) should be addressed and respected throughout the period of execution of REDD+ activities. Various existing policies, laws and regulations (PLRs) related to environment, forest, biodiversity, and right of local communities in India address and respect the Cancun safeguards. REDD + activities can be implemented in three phases, such as development of national strategies or action plans, implementation of national strategies or action plans that involve capacity-building of stakeholders and technology development and its transfer along 
with results-based demonstration activities with resultsbased actions that should be fully measured, reported and verified. The Warsaw Framework for REDD+ stated that from a variety of sources, namely public and private, bilateral and multilateral, including Green Climate Fund (GCF) and other funds be provided to developing country Parties for the implementation of REDD+ activities as results-based finance ${ }^{4}$. The Paris Agreement ${ }^{5}$ aims 'to strengthen the global response to the threat of climate change by keeping the global temperature rise well below $2^{\circ} \mathrm{C}$ above pre-industrial level'. According to the Paris Agreement, all country Parties must put forward their best efforts to tackle climate change through nationally determined contributions. The Paris Agreement recognizes the role of forests as a carbon sink for mitigation of climate change, and its Article 5 highlights that 'Parties should take action to conserve and enhance sinks and reservoirs of greenhouse gases including forests. Parties are encouraged to take action to implement and support, including through results-based payments, the existing framework as set out in related guidance and decisions already agreed under the Convention for policy approaches and positive incentives for REDD+ activities'.

India is under the readiness phase of REDD + implementation and developed its National REDD+ strategy and Forest Reference Level in 2018. The country is in the course of a development of a National Forest Monitoring System and Safeguards Information System for implementation of REDD+ activities. Rawat and Kishwan ${ }^{6}$ presented a climate change mitigation approach based on forest conservation for India, and advocated for compensating countries who work for carbon conservation through sustainable management of forests and enhancement of forest carbon stocks. Several other researchers have analysed existing policies, capacity and financial needs, opportunities, gaps and challenges for the implementation of REDD+ activities ${ }^{7-13}$.

A detailed review of published documents, reports and papers along with analysis of relevant existing national PLRs related to forest resource management of the country has been done here to provide an overview of opportunities and challenges anticipated for implementation of REDD+ activities in India.

\section{Opportunities for the implementation of REDD+ activities}

India's PLRs related to forests are conservation-centric, and focus mainly on enhancement of forest and tree cover to get sustainable flow of ecosystem goods and services for the welfare of forest communities. India has well established forestry institutions with a large number of forestry programmes and projects being implemented for achieving national targets and international commitments. These provide an enabling environment for the imple- mentation of REDD + activities. Opportunities identified for implementation of REDD+ activities are as follows.

\section{Policy and legislative frameworks}

The Government of India (GoI) has framed a number of PLRs periodically for the conservation of environment, forests, biodiversity and other natural resources, thereby providing an enabling environment for the implementation of REDD+ activities in the country (Table 1).

\section{Scientific management of forests}

Scientific management of forest began in India in 1864 . Forest working plans are the main instrument for scientific management of forests across the country. Working plans act as guiding documents for conservation and sustainable management of forests in India. This facilitate monitoring, evaluation and impact assessment of forest management practices being followed in the country. National Forest Policy, 1988 highlights the importance of management plans and clearly states that forests should not be worked without approved management plans ${ }^{14}$. In 1996, the Supreme Court of India had clarified that all working plans are to be approved by the Central Government. The Ministry of Environment, Forest and Climate Change (MoEFCC), GoI had adopted a uniform National Working Plan Code-2004 for preparation of working plans for forest management. It was reviewed in light of climate change impacts on forest ecosystem, role of forests in climate change mitigation and technological advancement in the field of Geographical Information System and remote sensing, and the new National Working Plan Code-2014 became effective from April 2014.

According to the new National Working Plan Code2014 , forest management planning must focus on sustainable management of the forest and its biodiversity as enclosed in the National Forest Policy, including ecological, economic and social dimensions ${ }^{15}$. According to the National Working Plan Code-2014, REDD+ has become an essential activity for forest planning and supports the implementation of REDD+ activities at the Forest Division level.

\section{Forestry research and training institutions}

MoEFCC has established forestry research and training institutions across the country for providing researchbased solutions for forestry problems and capacity building of State Forest Departments (SFDs), communities and other stakeholders in the conservation and sustainable management of forests and wildlife. The Indian Council of Forestry Research and Education is an apex body in the national forestry research structural framework that promotes need-based forestry research, education and extension through networks of nine institutes and five 
GENERAL ARTICLES

Table 1. Acts and policies related to forest conservation and supportive in the implementation of REDD + activities

\begin{tabular}{lc}
\hline Acts/policies & Supportive role in implementation \\
\hline Indian Forest Act, 1927 & $\begin{array}{c}\text { This Act consolidates the law relating to forests, transit of forest produce and duty leviable on timber and } \\
\text { other forest produce. Proper implementation of the provisions of this Act will help ensure } \\
\text { conservation of forests and also enhancing the quality and extent of forest and tree cover in the country } \\
\text { which, in turn, contribute to enhance REDD+ performance. }\end{array}$
\end{tabular}

Wild Life (Protection) Act, 1972

Forest (Conservation) Act, 1980

Environment (Protection) Act, 1986

National Forest Policy, 1988

Panchayat (Extension to Scheduled Areas) Act, 1996

Biological Diversity Act, 2002

National Environment Policy, 2006

The Scheduled Tribes and other Traditional Forest Dwellers (Recognition of Forest Rights) Act, 2006

National Agroforestry Policy, 2014

Green Highways Policy, 2015

Compensatory Afforestation Fund Act, 2016

Draft National Forest Policy, 2018
This Act provides protection to wild animals, birds and plants. It is perfectly linked with the adherence to safeguards of REDD+ relating to conservation of biodiversity.

This Act was enacted to reduce indiscriminate diversion of forest land for non-forestry purpose, and to regulate and control land-use changes in the forest. Ultimately it reduces deforestation through controlling the diversion of forest land.

This Act provides protection and improves the environment through prevention of pollution, and helps tackle specific environmental problems.

This policy aims to ensure environmental stability and maintenance of ecological balance. It ensures that the rights of the forest-dependent communities are protected. It also aims for maintaining one-third of the country's geographical area under forest and tree cover, and calls for massive afforestation and social forestry programmes with people's participation for increasing forest and tree cover in the country.

This Act has given special powers to the Gram Sabhas in scheduled areas, especially for the management of natural resources.

This Act deals with the conservation of biological diversity, sustainable use of its components, and fair and equitable sharing of the benefits arising out of the use of biological resources.

This policy was framed using the existing policies related to preservation of natural resources and is intended to guide action in developing regulatory reforms, and programmes and projects for environmental conservation. People depending on natural resources for their livelihood from conservation than from degradation of natural resources are the main subject of this policy.

This Act helps recognize and grant forest rights and occupation in forest lands of forest-dwelling scheduled tribes and other traditional forest-dwellers, who have been residing in such forests for generations. It also contributes towards adherence to the safeguards related to rights of the local communities with respect to their proprietorship of land and non-timber forest products.

This policy underlines the environmental contribution of agroforestry by preventing deforestation and promoting carbon storage, biodiversity conservation and soil and water conservation.

This policy provides vision of developing eco-friendly and green national highways. This afforestation drive has a target to plant 100 million trees along national highways.

The important feature of this Act is that any forest land being diverted to non-forest land, should be afforested equal to the size of the forest initially being converted. The Act has been enacted by the Government to systematically channelize the funds accrued on account of diversion of forest land. Funds are to be utilized for raising plantations, undertaking natural regeneration, protection of forests, Green India Programme, wildlife protection and other related activities.

This draft policy was framed with the view of attaining harmony with national interest, international commitments, rights and interest of forest-dependent communities, challenges of climate change, biodiversity conservation and sustainable management of forests for sustainable ecosystem services. Its main objectives are to maintain environmental stability and conservation of biodiversity, rehabilitate degraded forests, to maintain forest health, to increase tree cover outside forests by incentivizing agro-forestry and farm forestry, and to integrate climate change mitigation and adaptation measures in forest management through REDD+ so that the impacts of climate change can be minimized. centres located in different parts of the country. The Forest Survey of India (FSI) is involved in the preparation of national forest inventory on biennial basis. The Indira Gandhi National Forest Academy and Central Academy for State Forest Services are involved in building capacities of foresters of the Indian Forest Service and State Forest Services on forest and wildlife management. State-level Forest Training Schools are involved in building the capacities of frontline staff of SFDs. The Indian Institute of Forest Management provides training on the management of forest re- sources and related subjects to forestry professionals to equip them to practice the art and profession of management. The Wildlife Institute of India conducts research and provides training on the management and conservation of wildlife. Scientific inputs of research institutions and capacity-building support of training institutions can be utilized for the effective implementation of REDD+ activities. The National REDD+ Strategy 2018 has also highlighted the importance of research and training institutions in the implementation of REDD+ activities. 


\section{Forest governance and management}

Forests are in the concurrent list and jointly managed by the Union Government and State Governments. MoEFCC is responsible for framing national PLRs, conducting research and surveys, preparing national forest inventories, capacity building of forest officers, and providing financial support to state governments for the conservation of forests and wildlife. The state Governments/Union Territories (UTs) are responsible for the overall management and conservation of forests and wildlife in their respective states/UTs. Generally, a SFD has two main wings, namely territorial forests and wildlife. For proper management and conservation of forest resources, the territorial structure of the SFD has different units. Country-level territorial structure of the SFD comprises of 197 Forest Circles, 788 Forest Divisions, 4706 Forest Ranges, 11685 Forest Blocks and 43884 Forest Beats with a well-trained contingent of foresters at all levels numbering 140,680 (ref. 16).

\section{Community participation in the sustainable management of forests}

About 173,000 villages have been identified as forestfringe villages having more than 300 million people largely dependent on the forest for their livelihoods ${ }^{17}$. The concept of Joint Forest Management in India was initiated in 1990 with the aim to improve the quality of forests as well as the economic status of local communities involved in the protection and management of forests. About $22 \mathrm{~m}$ ha of forests in the country is being managed by about 118,000 Joint Forest Management Committees (JFMCs), with the involvement of more than 20 million people. JFMCs target conversion of low-productive forests to high-productive forests. Other innovative institutional arrangements for the management of forest resources are Van Panchayats in Uttarakhand. The Van Panchayat Act was enacted in 1931 under Section 28(2) of the Indian Forest Act, 1927. In Uttarakhand, 12,067 Van Panchayats manage about 522,000 ha of forests ${ }^{18}$.

Community forest management systems have existed in diverse forms throughout North-East India and continue to be the primary mode of forest conservation and protection. In Nagaland and Meghalaya, over $90 \%$ of the forests are under direct control of traditional village institutions, communities and individuals. About $1.84 \mathrm{~m}$ ha of forests is under the management of Autonomous District Councils in Assam, Meghalaya, Mizoram and Tripura, which are traditionally owned and managed by tribal and local communities $^{16}$.

There is an ample opportunity for integrating REDD+ initiatives with community-managed forests. Promoting and integrating REDD+ activities into community forest management for the enhancement of forest carbon stocks will meet both national objectives and international commitments of climate change mitigation.

\section{Major programmes and projects in the forestry sector}

India is playing a positive role in the mitigation of climate change through enhancing forests and tree cover by implementing various programmes and missions. Table 2 provides details of major programmes and projects undertaken by GoI.

Several programmes and activities implemented by State Governments like Green Army of Maharashtra, Telangana $\mathrm{Ku}$ Haritha Haaram, and Ama Jungle Yojana of Odisha, etc. help conduct massive plantation programmes to increase the forest and tree cover. The Eco-task Force under Ministry of Defence, GoI is also involved in large-scale plantation programmes in different parts of the country.

\section{Status of forest and carbon stocks in India}

India ranks tenth among the most forested nations of the world $^{19}$, and its forest and tree cover are continuously increasing. Recorded forest area of India according to Government records is 767,419 sq. $\mathrm{km}$, which is $23.34 \%$ of the total geographical area. Total forest cover according to the 16th assessment is 712249 sq. $\mathrm{km}(21.67 \%$ of the total geographical area). Forest cover of 3976 sq. km has increased at the national level during the assessment period 2017-19. Tree cover according to the 16th assessment is estimated to be 95,027 sq. $\mathrm{km}(2.89 \%$ of the total geographical area). Tree cover of $1212 \mathrm{sq} . \mathrm{km}$ has increased at the national level during the assessment period 2017-2019. Total forest and tree cover of the country is 807,276 sq. $\mathrm{km}(24.56 \%$ of the total geographical area). Forest carbon stocks of $7124.6 \mathrm{mt}$ have been estimated for the year 2019 (ref. 20). Over the past decades, national policies and acts as well as national and states-level forestry programmes and projects have transformed the country's forests into a net sink of carbon dioxide. This clearly shows the opportunities for implementation of REDD+ activities.

\section{Technological advancement for preparation of national forest inventory}

India is among the few countries which regularly use satellite-based remote sensing technology for the preparation of national forest inventory. Application of remote sensing technology to assess forest cover and tree cover of the entire country began in the early 1980s. FSI is involved in the assessment of forest cover of India biennially. The first nationwide remote sensing-based assessment was done in 1987 using LANDSAT-MSS sensor with a spatial resolution of $80 \mathrm{~m}$. The scale of mapping 
GENERAL ARTICLES

Table 2. Major programmes and projects undertaken in the forestry sector

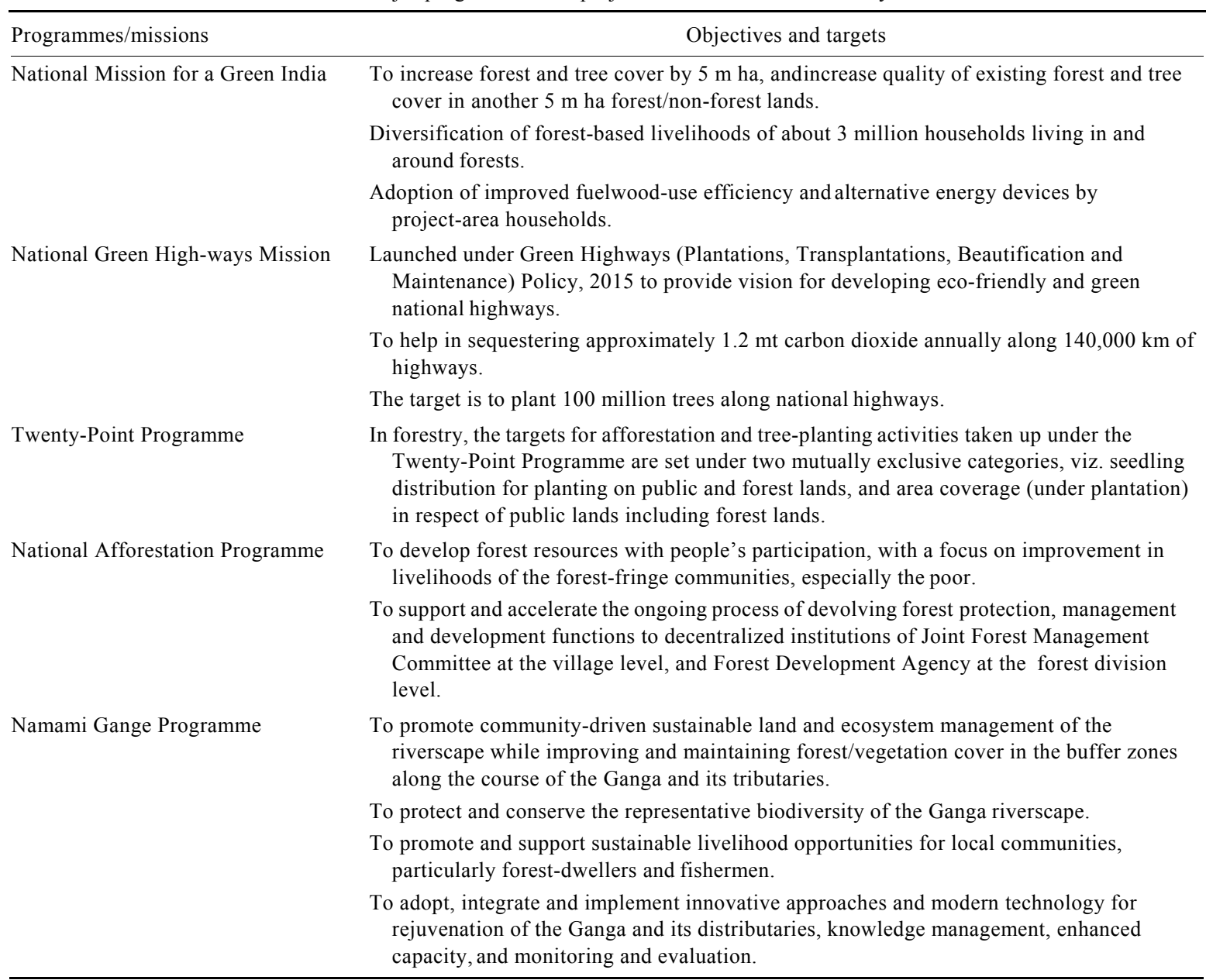

was $1: 1,000,000$ and mode of interpretation was visual with minimum mappable units from 400 to 25 ha. FSI has started using indigenous remote sensing satellite data since 1995 and gradually shifted the mode of interpretation from visual to digital. IRS-Resourcesat-2 and LISSIII sensor with a spatial resolution of $23.5 \mathrm{~m}$ and scale of interpretation of 1:50,000 have been used. Shift from visual to digital mode of interpretation was made and has advanced to reduced size from 25 ha to 1 ha (ref. 20). This practice has tremendous application in measuring, reporting and verification of performance of REDD+ activities.

\section{Checking forest degradation}

Deforestation at a large scale is not evident in India. However, dependency of local communities on forests for their livelihoods is causing degradation. According to India State of Forest Report 2019, very dense forest is spread over $99,278 \mathrm{sq}$. $\mathrm{km}(13.93 \%$ of the total forest cover), moderately dense forest $308,472 \mathrm{sq}$. $\mathrm{km}(43.30 \%$ of the total forest cover) and open forest $304,499 \mathrm{sq} . \mathrm{km}$ (42.75\% of the total forest cover). A degraded forest area with canopy density of less than $10 \%$ is known as scrub, which is spread over an area of 46,297 sq. km (ref. 20). Forest degradation could be best addressed in an integrated manner for converting low-density forests into high-density forests through implementation of REDD+ activities.

\section{Achieving the National Forest Policy goal}

India is one of the few countries where forest and tree cover has shown an increment in recent years, transforming the country's forests into a net sink of carbon owing to national policies aiming at conservation and sustainable management of forests. According to the latest assessment, forest and tree cover has increased from $23.4 \%$ of the total geographical area in 2005 to $24.56 \%$ in 2019. Implementation of REDD + activities can play a crucial role in achieving the long-term goal of GoI of bringing 33\% of its geographical area under forest and tree cover, as envisaged in the National Forest Policy.

\section{National Action Plan on Climate Change}

India's National Action Plan on Climate Change (NAPCC) was launched in 2008. This has helped identify several 
measures that focus on advancing the country's development and climate change-based objectives that work both on adaptation and mitigation aspects. Implementation of NAPCC is designed to take place through eight National Missions (Green India Mission, Solar Mission, Mission for Enhanced Energy Efficiency, Mission on Sustainable Habitat, Water Mission, Mission for Sustainable Agriculture, Mission for Sustaining the Himalayan Ecosystem, and Mission on Strategic Knowledge for Climate Change $)^{21}$, which form the central part of NAPCC and incorporate multidimensional, long-term strategies to achieve India's key goals in the context of climate change.

\section{Nationally Determined Contribution goal}

The Paris Agreement recognizes the role of forests as principal in achieving the goal of keeping temperatures well below $2^{\circ} \mathrm{C}$ through mitigation activities aiming to reduce emissions from deforestation and forest degradation. India's Nationally Determined Contribution (NDC) goal for the forestry sector is to create an additional carbon sink of 2.5-3.0 billion tonnes of $\mathrm{CO}_{2}$ equivalent through additional forest and tree cover by 2030 (ref. 22). Implementation of REDD+ activities has been identified as one of the tools to meet the NDC goal of forestry sector.

\section{National Biodiversity Targets, 2014}

Addendum of the National Biodiversity Action Plan, 2008 prepared by India in 2014, consists of 12 national biological diversity targets which are related to awareness generation about the values of biodiversity and its conservation, integration of biodiversity values in national and state planning processes, development programmes and poverty alleviation strategies, strategies for reducing the rate of degradation and loss of all natural habitats, management of invasive alien species, sustainable management of forests, conservation of species-specific ecological areas, maintenance of genetic diversity of cultivated plants, farm livestock and their wild relatives, valuation of ecosystem services, access to genetic resources and the fair and equitable sharing of benefits arising out of utilization, and documentation and strengthening of traditional knowledge related to biodiversity. The National biodiversity targets can also be achieved through implementation of REDD+ activities. Moreover, achieving the national biodiversity targets will help in the fulfilment of safeguards for REDD+ (ref. 23).

\section{India's National REDD+ strategy 2018}

Development of the National REDD+ Strategy is one of the mandatory requirements for the implementation of REDD + activities. Objective of the National REDD+ Strategy 2018 is to facilitate the implementation of REDD+ programme in the country in conformity with relevant decisions of UNFCCC. The strategy has focused on creation of trained human resource capable for carrying out forest related measurements at multi levels in view of REDD+ implementation. The National REDD+ Strategy provides a road map for addressing drivers of deforestation and forest degradation, and proposes to establish a National Governing Council for REDD+ to coordinate and guide $\mathrm{REDD}+$ related actions at the national level. A National Designated Entity for REDD+ shall also be established by the MoEFCC, GoI to liaise with UNFCCC and the states. The strategy has devolved major responsibility for the execution of REDD+ activities on SFDs. The states have to create a REDD+ Cell in the SFDs and prepare their State REDD+ Action Plan for implementation of the National REDD+ Strategy ${ }^{17}$.

\section{Forest Reference Level}

The national forest reference level (FRL) serves as a benchmark to assess the performance of implementation of REDD+ activities in the country. It is also one of the mandatory requirements for the implementation of REDD + activities. All five pools such as aboveground biomass, belowground biomass, deadwood, litter and soil organic carbon have been accounted in the FRL. Only $\mathrm{CO}_{2}$ as a GHG in the period from 2000 to 2008 have been considered for FRL. Submission of the national FRL was made by GoI to UNFCCC in January 2018, which has been technically reviewed. India's FRL for the period under reference is $-49.70 \mathrm{mt} \mathrm{CO}_{2}$ equivalent per year ${ }^{-1}$ (ref. 24).

\section{Green skill development programme}

MoEFCC, GoI, has taken an initiative to develop green skills in both environment and forest sectors to enable India's youth to gain through self-employment and/or employment by SFDs. The National REDD+ Strategy will support empowerment of youth cadres as Community Foresters, who can be engaged effectively in assisted natural regeneration, soil and moisture conservation, harvesting, thinning and hygienic removals, forest nurseries and raising of quality planting stocks, and prevention and control of forest fires, pests and diseases, and spread of invasive alien plant species through green skill development ${ }^{17}$.

\section{International commitments}

REDD+ has a potential to bring synergies among all three Rio Conventions on biodiversity, climate change and combating desertification. Implementation of REDD+ activities can play a crucial role in achieving international commitments related to forestry sector under the Paris Agreement of UNFCCC, Aichi Biodiversity Target of Convention on Biological Diversity, Land Degradation Neutrality Target of the United Nations Convention to Combat Desertification, Global Forest Goals of the 
United Nation Forum on Forest, pledge under Bonn Challenge and Sustainable Development Goals 13 and 15.

\section{Taping of finance for REDD+ activities}

The REDD+ mechanism under UNFCCC is agreed in accordance with Cancun Agreements, many bilateral and multilateral funding mechanisms are ready for a quick start of REDD+ activities. GCF was set up by the country Parties of UNFCCC in 2010 as a part of the financial mechanism. It assists the efforts of developing countries responding to the challenges due to climate change, and also helps them to limit or reduce their GHG emissions and adapt to climate change. Developing country Parties can access GCF support for activities across all three phases (readiness, implementation and results-based payment) of REDD+. National funding such as the CAMPA fund is intended for undertaking compensatory afforestation, assisted natural regeneration, conservation and protection and other related activities. Taping of international financial support from GCF can provide an opportunity for implementation of REDD+ activities in India including during the readiness phase.

\section{Challenges in the implementation of REDD+ activities}

Though India is progressing in the implementation of REDD + activities, some challenges have been identified as discussed below.

\section{Lack of readily available finance}

REDD+ is an incentive-based mechanism for promoting and rewarding stabilization, maintenance and enhancement of forest carbon stocks in developing countries as a mitigation measure for climate change. Readily available finance is one of the constraints for implementation of the National REDD+ Strategy and adequate, predictable and sustainable flow of financial resources is needed for result-based actions. Kohli et al. ${ }^{25}$ emphasized that all sources of financing, both public and private, should be taken into consideration for results-based actions.

\section{Role of private sector}

The private sector has the potential to play an important role in the implementation of REDD+ activities mainly related to conservation and enhancement of forest carbon stocks through providing finance from their corporate social responsibility funds. Guidelines need to be developed to include the roles and responsibilities of the private sector in the implementation of REDD + activities. The private sector can be involved in raising and providing quality planting stocks of indigenous forestry species for productivity enhancement and restoration of degraded forest lands. It can also be involved in supporting the demonstration activities and providing alternate climatefriendly technologies to local communities for reducing pressures on forest-based resources. Additionally, the private sector can help establish cottage-based and other small-scale industries to support alternate incomegeneration activities for communities depending upon forest resources.

\section{Lack of capacity of stakeholders}

Capacity building of frontline staff of SFDs and local communities for carrying out measurements, reporting and verification of forest carbon stocks is required for the successful implementation of REDD + activities. Local communities and other forest-dwellers are also important stakeholders and need to build their skills on various aspects of forest conservation, viz. assisted natural regeneration, social and environmental safeguards, soil and water conservation measures, forest fire protection, control of invasive species, pest and disease management, and alternate income-generation activities which will support SFDs in the implementation of REDD+ activities.

\section{Availability of quality planting stocks}

Indian forests have a productivity of $1.34 \mathrm{~m}^{3} / \mathrm{ha} /$ year against the world average of $2.1 \mathrm{~m}^{3} / \mathrm{ha} /$ year (ref. 26). One of the major causes for low productivity is the nonavailability of quality planting stocks for forestry plantations. Availability of quality planting stocks can substantially enhance the quality as well as productivity of forests. High population pressure and land availability also become a limitation for forest managers to enhance forest productivity. India is also striving to enhance its forest and tree cover to one-third of the total geographical area of the country. Therefore, it is essential to make available quality planting stocks for forest productivity enhancement. The National REDD+ Strategy of India also advocates development of Reproductive Planting Material Certification Policy-cum-Strategy ${ }^{16}$.

\section{Control of rising forest fires}

Fire is one of the major drivers of forest degradation which adversely impact the flow of ecosystem goods and services as well as health of the forest ecosystem. Gaps created due to high-intensity fires are susceptible to invasion by exotic species which spread rapidly, thus making the establishment of native species difficult. Every year fires affect large areas of forests with varying intensity and extent. FSI has reported 33,664 incidences of forest fire during 2016 and 37,059 during 2018 (ref. 20) mainly in the tropical moist deciduous forests, tropical semi-evergreen forests, tropical dry deciduous forests, 
sub-tropical broadleaved hill forests and sub-tropical pine forests $^{20}$. Policy needs to be developed for addressing forest degradation and to check carbon emission through forest fires.

\section{Forest degradation by invasive alien plant species}

The forest ecosystem is under degradation due to rapid invasion of invasive alien plant species which are one of the major drivers of forest degradation and contribute to loss of biodiversity, altering both ecosystem structure and functioning, thereby affecting provision of ecosystem services. The Indian region is highly vulnerable to biotic invasion because of its diverse climate and environmental conditions. The most common exotic species of India are Lantana camara, Eupatorium adenophorum, Mikania micarantha and Parthenium hysterophorus ${ }^{27}$. There is an urgent need to develop a policy and appropriate strategies for the management and control of invasive alien species which will definitely be helpful in checking forest degradation and biodiversity loss.

\section{Conclusion}

PLRs related to conservation of forests, biodiversity, environment and wildlife; well-structured forestry institutions at the Centre and state level and ongoing forestry programmes and projects are subsets for the implementation of REDD+ activities in India. International finance needs to be tapped from GCF, etc. for all phases of REDD+ implementation in the country. Investments from both public and private sector for implementation of REDD+ activities need to be ensured and their role in the enhancement of forest carbon stocks related activities needs to be assigned. Capacity of frontline staff and local communities in forest-fringe villages also needs to be developed through establishment and strengthening of state REDD + Cells for the implementation of REDD+ activities.

1. IPCC, IPCC special report on climate change, desertification, land degradation, sustainable land management, food security, and greenhouse gas fluxes in terrestrial ecosystems. Intergovernmental Panel on Climate Change, Geneva, Switzerland, 2019.

2. UNFCCC, Decision 2/13. Reducing emissions from deforestation in developing countries: approaches to stimulate action. United Nations Framework Convention on Climate Change, Bonn, Germany, 2007.

3. UNFCCC, Decision 1/CP.16. Cancun Agreements. United Nations Framework Convention on Climate Change, Bonn, Germany, 2010.

4. UNFCCC, Technical synthesis on the new market-based mechanism. Technical Paper 22, FCCC/TP/2013/6, United Nations Framework Convention on Climate Change, Bonn, Germany, October 2013

5. UNFCCC, Decision 1/CP.21. Paris Agreement. United Nations Framework Convention on Climate Change, Bonn, Germany, 2016.

6. Rawat, V. R. S. and Kishwan, J., Forest conservation based climate change mitigation approach for India. Int. For. Rev., 2008, 10(2), 269-280.
7. Agarwal, A., Das, S. and Paul, V., Is India ready to implement REDD-plus? A preliminary assessment. The Energy and Resource Institute, New Delhi, 2009.

8. Pant, P., Sharma, P. Jain, S. and Gregoire, T. G., Analysis of REDD for India: Opportunities and Challenges, VDM Verlag Dr Müeller, Germany, 2010.

9. TERI, Proceedings of National-level Consultation on International REDD-plus Architecture and its Relevance for India. The Energy and Resource Institute, New Delhi, 2012.

10. Sud, R., Sharma, J. V., Bansal, A. K. and Chandra, S., Institutional framework for implementing REDD+ in India. The Energy and Resources Institute, New Delhi, 2012.

11. Sharma, V. and Chaudhry, S., An overview of Indian forestry sector with REDD+ approach. ISRN For., 2013, 1-10.

12. Vijge, M. J. and Gupta, A., Framing REDD+ in India: carbonizing and centralizing Indian forest governance. Environ. Sci. Policy, 2014, 38, 17-27.

13. Singh, T. P., Rawat, V. R. S. and Rawat, R. S., Implementing REDD + as a climate mitigation option in India. Indian For., 2015, 141(1), 9-17.

14. MoEF, National Forest Policy 1988, Ministry of Environment and Forest, Government of India (GoI), 1988.

15. MoEFCC, Reference Document for REDD+ in India, Ministry of Environment, Forest and Climate Change, GoI, 2014.

16. ICFRE, Forest Sector Report India 2010, Indian Council of Forestry Research and Education, Dehradun, 2010.

17. MoEFCC, National REDD+ Strategy, Ministry of Environment, Forest and Climate Change, GoI, 2018.

18. Chauhan, M., A perspective on watershed development in the Central Himalayan state of Uttarakhand, India. Int. J. Ecol. Environ. Sci., 2010, 36(4), 253-269.

19. FAO, Global Forest Resource Assessment 2010, Food Agriculture Organization, Rome, Italy, 2010.

20. FSI, India State of Forest Report 2019, Forest Survey of India, Dehradun, 2019.

21. Usman, A., Sustainable development through climate change mitigation and biomass agriculture: India's perspective. In IEEE Conference on Technologies for Sustainability, Phoenix, AZ, USA, 12-14 November 2017, pp. 1-7.

22. https://www4.unfccc.int/sites/submissions/INDC/Published $\% 20$ Documents/India/1/INDIA\%20INDC\%20TO\%20UNFCCC.pdf, 2015 (accessed on 31 August 2019).

23. MoEFCC, Implementation of India's National Biodiversity Action Plan: an overview. Ministry of Environment, Forest and Climate Change, GoI, 2019.

24. UNFCCC, Report of the technical assessment of the proposed forest reference level of India submitted in 2018 (FCCC/TAR/ 2018/IND). United Nations Framework Convention on Climate Change, Bonn, Germany, 2018.

25. Singh, M. P., Singh, T. P. and Rawat, V. R. S., REDD+ in India: from negotiations to implementation preparedness. In Proceedings of the Regional Workshop on Learning on Reducing Emissions from Deforestation and Forest Degradation (eds Karki, S., Joshi, L. and Karky, B. S.), International Centre for Integrated Mountain Development, Kathmandu, Nepal, 2014.

26. Planning Commission, Eleventh Five-Year Plan (2007-2012). Agriculture, rural development, industry, services and physical infrastructure. Planning Commission, GoI, 2008.

27. Kohli, R. K., Dogra, K. S., Batish, D. R. and Singh, H. P., Impact of invasive plants on the structure and composition of natural vegetation of North Western Indian Himalayas. Weed Technol., 2004, 18, 1296-1300.

Received 5 November 2019; revised accepted 22 June 2020

doi: $10.18520 / \mathrm{cs} / \mathrm{v} 119 / \mathrm{i} 5 / 749-756$ 